\title{
Alkaloid content of South African lupins (L luteus, $L$ albus and L angustifolius species) and determination thereof by Near Infra-red Reflectance Spectroscopy
}

\author{
T.S. Brand ${ }^{1}$ and D.A. Brandt ${ }^{2}$ \\ ${ }^{1}$ Elsenburg Agricultural Research Centre, P Bag X1, Elsenburg, 7607 , South Africa; ${ }^{2}$ OTK, PO Box 100, Bethal 2310, South \\ Africa \\ e-mail: tersb@wcape.agric.za
}

\section{Introduction}

Lupins play an important role as an alternative crop in the Western Cape. Approximately 2000 ha sweet yellow lupins (Lupinus luteus), 16000 ha broad-leafed lupins (Lupinus albus) and 16000 ha narrow-leafed lupins (Lupinus angustifolius) are presently cultivated in the Western Cape winter rainfall region (Protein Research Trust, 1999). Lupins are used mainly as an alternative protein source by both monogastric (Brand et al, 1995) and ruminant animals (Brand et al, 1992; Brand et al, 1997). Both Lupinus albus and Lupinus angustifolius, however may contain unacceptedly high levels of alkaloids, which are detrimental to animals. Pearson \& Carr (1977) as well as Ruiz (1977) found that food rejection may occur when the alkaloid content of the diet exceeds $0.03 \%$, while Erickson \& Elliot (1984) found that growth performance of pigs is depressed when the ration contains 0.04 $\%$ alkaloids. The feed manufacturing industry therefore is cautious with the use of lupins in diet formulations, while the Australian lupin industry even prescribed a maximum alkaloid content of $0.07 \%$ in the grain itself (Grain Pool of Western Australia, 1999). Determination of alkaloids in lupins by the reliable capillary gas chromatography techniques is, however, too expensive (R700 to R1 200 per sample) for the routine analysis of lupins. The objectives of this study were to (i) determine the alkaloid levels in the lupin cultivars cultivated in South Africa and (ii) to evaluate near infra-red reflectance spectroscopy (NIRS) as a less expensive but reliable quantitative method to determine total alkaloids in lupins.

\section{Materials and Methods}

Cultivars of different types of lupins cultivated in the Western Cape were collected over two seasons. The seeds were analysed for total alkaloids by capillary gas chromatography (CSIR, Pretoria). Thirty-three spectra were use as a calibration set for the determination of alkaloids by NIRS. Ten samples were used in the validation process. Methods are described in detail by Bran \& Luebbe (1994).

\section{Results and Discussion}

The alkaloid contents of the different South African lupin types and cultivars are presented in Table 1.

Table 1 Alkaloid content of South African lupin types and cultivars.

\begin{tabular}{|c|c|c|c|c|}
\hline \multirow[t]{2}{*}{ Lupin type and cultivar } & \multirow{2}{*}{$\begin{array}{l}\text { Number of } \\
\text { samples (n) }\end{array}$} & \multicolumn{3}{|c|}{ Alkaloid content (ppm)+ } \\
\hline & & Min & $\operatorname{Max}$ & Mean \\
\hline \multicolumn{5}{|l|}{ Lupinus luteus } \\
\hline Juno & 2 & 20.0 & 50.1 & 35.1 \\
\hline Borsaja & 2 & 0.0 & 35.1 & 17.5 \\
\hline \multicolumn{5}{|l|}{ Lupinus albus } \\
\hline Astra & 2 & 175.0 & 1670.0 & 923.0 \\
\hline Buttercup & 3 & 689.0 & 2673.0 & 1592.0 \\
\hline Hamburg & 3 & 784.0 & 5038.0 & 3124.0 \\
\hline Kiev & 5 & 141.0 & 1915.0 & 868.0 \\
\hline Esta & 10 & 703.0 & 2637.0 & 1276.0 \\
\hline Vladimir & 2 & 156.0 & 1256.0 & 706.0 \\
\hline Hantie & 3 & 1799.0 & 3366.0 & 2678.0 \\
\hline Swartland & 3 & 410.0 & 730.0 & 460.0 \\
\hline \multicolumn{5}{|l|}{ Lupinus angustifolius (sweet) } \\
\hline Eureka & 2 & 35.2 & 80.8 & 58.0 \\
\hline Helderberg & 2 & 20.0 & 38.0 & 29.0 \\
\hline Merrit & 2 & 24.2 & 67.3 & 45.8 \\
\hline \multicolumn{5}{|l|}{ Lupinus angustifolius (bitter) } \\
\hline Moredou & 2 & 13925 & 16484 & 15205 \\
\hline
\end{tabular}

${ }^{+}$To convert to percentage: $\mathrm{x} / 10000$ 


\section{Short paper and poster abstracts: $38^{\text {th }}$ Congress of the South African Society of Animal Science}

It was evident from the data that Lupinus luteus cultivars contain low levels of alkaloids as expected. The Lupinus angustifolius cultivars bred for low alkaloid content showed low levels of alkaloids with a small variation among samples. Large variation in alkaloid content, however, occurred among samples of the same cultivars as well as among different cultivars of Lupinus albus seed. This large variation in the alkaloid content of Lupinus albus seed and less variation in the alkaloid content of sweet Lupinus angustifolius seed is probably related to the fact that there is considerably higher degree of out-crossing with Lupinus albus compared to Lupinus angustifolius (Green et al, 1980). A genetic marker has also been incorporated in sweet Lupinus angustifolius, which is not the case with Lupinus albus. Plants that contain alkaloids are also more genetically fit than those that do not (Green et $a l, 1980)$, and there can be a rapid shift of the population back to bitter material. The relationships between the NIRS predicted alkaloids and actual alkaloids as determined by capillary gas chromatography are presented in Table 2.

Table 2 The relationship between the NIRS predicted and actual alkaloids.

\begin{tabular}{ccc}
\hline Sample number & $\begin{array}{c}\text { Actual alkaloids determined by gas } \\
\text { chromatography }(\mathrm{ppm})+\end{array}$ & $\begin{array}{c}\text { Predicted alkaloids determined } \\
\text { by NIRS }(\mathrm{ppm})+\end{array}$ \\
\hline 1 & 239 & 466 \\
2 & 689 & 472 \\
3 & 758 & 2613 \\
4 & 1380 & 782 \\
5 & 1771 & 1500 \\
6 & 2673 & 3192 \\
7 & 3549 & 3384 \\
8 & 5113 & 4483 \\
9 & 9487 & 11547 \\
10 & 13925 & 15550 \\
\hline Regression equation: $\mathrm{Y}=-52.456+1.125 \mathrm{x}$ \\
$\mathrm{R}^{2}=0.98$ & & \\
$\mathrm{SE}=924$ & & \\
${ }^{+}$To convert to percentage: $\mathrm{x} / 10000$ &
\end{tabular}

The correlation coeficient $\left(\mathrm{R}^{2}\right)$ between NIRS predicted values and gas chromatography values was 0.98 , which indicated that NIRS can be used as a rapid indirect method to determine the alkaloid content of lupins.

\section{Conclusions}

The study indicates that care must be taken when Lupinus albus seed is used in diets for monogastric animals, since there is a large variation in the alkaloid content. Seed of Lupinus angustifolius maintains a low and relatively stable alkaloid content. NIRS appears to be a valuable tool for the rapid (and less expensive) determination of the alkaloid content of lupins.

\section{Acknowledgements}

This study was financed by the Protein Research Trust and the Red Meat Development Trust.

\section{References}

Brand, T.S. et al., 1997. Small Rum. Res. 26: 93.

Brand, T.S. et al., 1992. S. Afr. J. Anim. Sci. 22: 170.

Brand, T.S. et al., 1995. S. Afr. J. Anim. Sci. 25: 31.

Bran \& Luebbe, 1994. Bran \& Luebbe, Werkstrabe 4, 22844 Norderstedt, Germany.

Erickson, J.P. \& Elliot, F.C., 1984. Proc 3rd International Lupin Conference, France. pp 623.

Grain Pool of Australia, 1999. Grain Pool of Western Australia. St Georges Terrace, Perth, Western Australia. Pp. 172-176.

Green, A.G. et al., 1980. Z Pflzücht 84: 181.

Pearson, G. \& Carr, J.R., 1977. Anim. Feed Sci. Technol. 2: 49.

Protein Research Trust, 2000. Elsenburg, January 2000.

Ruiz, L.P., 1977. NZ. J. Agric. Res. 20: 51. 